\title{
The "happiness" concept in the Japanese and English cultures: comparative analysis
}

\author{
Larisa Vladimirovna Tarasova $^{1 *}$ and Maria Kostrova ${ }^{2}$ \\ ${ }^{1}$ I.N. Ulianov Chuvash State University, Faculty of foreign languages, Chair of Romano-Germanic \\ Philology and Translation Studies, Cheboksary, Russia \\ ${ }^{2}$ State Linguistic University of Nizhny Novgorod named after N. A. Dobrolyubov, Department of \\ Theory and Practice of English Language and Translation, Nizhny Novgorod, Russia
}

\begin{abstract}
The study aims at examining the concept of "happiness" and its manifestations in Japanese and English. At the same time, there is no task to highlight specific features of the conceptual sphere in Great Britain, the USA and Australia. The main emphasis is placed on the comparative aspect, which also conditioned the use of the comparative method in the article. When describing the semantic field of the "happiness" concept in the Japanese culture, it is important to consider the influence of hieroglyphs borrowed from China, values and ideas about the organization of social life, the role of traditional beliefs, everyday magic and kotodama (the soul of language). Finally, it is worth mentioning the broad synonymous content of the "happiness" conceptual field in the dictionary "Ruigo reikai jiten". It combines the native Japanese 幸せ shiawase "happiness" and 幸い saiwai with the Sinicisms containing the hieroglyphs 福 fuku and 幸運 ko:un "luck". At the same time, 運 un "fate, luck" is among the following synonyms: 天命 tenmei (“destined by the sky”), 命運 meiun and others, representing the concept of "fate". In the course of the study, the authors have emphasized the influence of ethical ideas contained in the axiologeme do:toku 道徳 and the desire for harmony on the Japanese culture. In the English-speaking cultures, this ethical component becomes secondary in comparison with materially expressed success and luck, the principle of preserving one's own freedom and independence. However, the impact of time (globalization, Internet communication, the dominance of English) gradually led not only to the emergence of Anglicisms in the Japanese culture but also to a change in the content of significant concepts, in particular the concept of "happiness".
\end{abstract}

Keywords: Japanese and English languages, concept, axiologeme, impact.

\section{Introduction}

The concept of "happiness" is among the main concepts in all linguistic cultures. It manifested itself in different historical epochs. However, most orientalists argue that the current understanding of this concept goes back to traditional values and ethical foundations

*Corresponding author: 21d12@mail.ru 
of the Japanese culture [1]. At the same time, the English-speaking tradition refers to a more trivial interpretation (happiness as luck or success) [2:3].

\section{Methods}

This research is based on the conceptual analysis of precedent cultural texts and the comparative analysis of concepts from various linguistic cultures. The article refers to the issues of studying the Japanese and English languages, as well as intercultural communication $[3,4]$.

\section{Results and discussion}

Considering "happiness" in the conceptual sphere of the Japanese language, it is necessary to point out several features of the Japanese linguistic culture. Although Japan experienced a long period of isolation from the outside world, its culture paradoxically retained its readiness to borrow. Until modern times, Japan and the Japanese language were strongly influenced by the Chinese civilization along with other countries and languages of Southeast Asia. This resulted in a huge number of Kango (the Chinese-derived words) both in books and in everyday speech. While describing concepts as units of the Japanese linguistic culture, the Chinese influence matters for several reasons.

Hieroglyphs borrowed from China became one of the factors that determined the socalled "word problem" in Japanese. In relation to other languages the definition of "a word as the basic unit of a language" seems self-evident, but the problem of word (lexeme) extraction often does not have a single solution in Japanese. Thus, E.V. Mayevskii asked the following question: what are relations between 体 and 體 (the modern and old writing of the same hieroglyph meaning "body"), karada ("body, organism"; an original Japanese word) and tai (the Chinese version formed in the process of mastering hieroglyphs in Japanese; it is not used separately but is part of complex words: for example, taiiku-physical education)? Should they be considered one word or several? [5: 84].

When describing the concept of "happiness", this feature of the Japanese language raises the question of what the name of the concept is: a native Japanese pre-written word (for example, shiawase) or one of the many hieroglyphs meaning "happiness, luck, fun" (for example, 喜, 運, 福, etc.). The same goes for multiple representations of this concept.

The issue of happiness and good luck worries the Japanese as much as other peoples. As a result, a large number of signs and beliefs have developed in Japan. In the atmosphere of religious tolerance, everyday magic flourishes, where ideas about kotodama (the soul of language) play a prominent role [6]. On the one hand, they conditioned a tradition (dating back to the Chinese culture) to apply hieroglyphs symbolizing wishes on postcards, gift wrapping, signboards, etc. On the other hand, they promote the formation of ideas about imikotoba (taboo words that should be avoided in certain situations). For instance, words denoting doubling or repetition (kasane gasane, futatabi, etc.) are unacceptable in solemn speeches at a wedding and funeral. The kiru verb (cut) and some others are also prohibited at a wedding. Both customs are well shown in the educational comic "Tabeta-ke ga iku!" [7: $178 ; 164-165]$. Lists of imi-kotoba can be found in any manual of etiquette, for example, in a letter-book [8: 134-137]. Thus, rituals and expressions associated with everyday and verbal magic can be attributed to the basic concept of "happiness".

The analysis of synonyms provides some information about the concept of "happiness" in the Japanese linguistic culture. Thus, the dictionary "Ruigo reikai jiten" unites the native Japanese 幸せ shiawase "happiness" and 幸い saiwai “fortunately" with Sinicisms containing the hieroglyph 福 fuku and 幸運 ko:un "luck" (literally, “fortunate fate") and the 
above-mentioned borrowings ラッキ rakki: (from the English “lucky”). At the same time, 運 un "fate, luck" is separately included into the list of synonyms 天命 tenmei ("destined by the sky"), 命運 meiun, etc., referring rather to representations of the "fate" concept [9]. A more complete dictionary "Ruigo Shinjiten" follows the same principle: shiawase, synonyms under the same hieroglyph and the Sinicisms containing fuku form a synonymic row entitled 禍福 kafuku ("adversity and happiness"). Another row comprising combinations of the un hieroglyph and its synonyms is contained in the entry above under the title 運命 ummei "destiny". Both rows in the complex structure of the dictionary are included into the semantic field 性向 seiko: “properties, features” / 境遇 kyo:gu “circumstances” [10: 568]. Neither dictionary fills rows with synonyms for the yürashia adjective "happy, joyful" or the yorokobu verb "to rejoice". Thus, the concept of shiawase reflects the interpretation of happiness as a fact of life or one's fate [11: 989].

The cultural correlation of the "happiness" concept with the traditional doctrine of do:toku 道徳 is also significant. This word of Chinese origin has several meanings: the hieroglyph 道 denotes one's way, duty, morality, teaching, means; the second element 徳 is translated as morality and virtue [12: 253-258]. The Japanese brought up in the spirit of do:toku should have the ability to self-denial sutemi 捨て身 and selflessness muyoku 無欲 (literally, the lack of desires), self-sacrifice giseishin 犠牲心, the desire for mutual help and the willingness to compromise gojo-gojo 互助互譲. The latter principle requires that the interests of society (company or family) should be taken into account more often than the interests of an individual.

Individualism is more typical of the English culture. The English-speaking world is based on such values as privacy, the inviolability of property based on personal freedom and civil liberty [13].

Modesty and restraint (kenkyo 謙虚), as well as shyness and delicacy (haji 恥) are common to the public behavior of the Japanese. A man of honor can never commit an act for which they will be ashamed in front of others. Y. Mishima noted that the Japanese morality is "the morality of close attention to the external aspect of life. The Japanese always ask themselves a question: will I embarrass myself? Will the others despise me? It was thought more important to look healthy than to be healthy, and more important to seem bold and daring than to be so" [14: 2-68]. If the Japanese commit inappropriate actions, put others in an uncomfortable situation, violate the established order, they experience the feeling of guilt - tsumi 罪.

On the contrary, the English culture is characterized by respect for originality, courage, unusual appearance, behavior and self-realization. The sense of humor is sometimes valued higher than social success.

Two more concepts traditionally make up the harmony of life for the Japanese: giri-ninjo 義理人情 and bushido 武士道 (literally, “the way of the warrior"), which is the basis of the samurai ethics. Giri is usually translated as a "moral duty": the hieroglyph gi 義 has such meanings as "justice, honor, dedication, chivalry"; $r i$ 理 stands for "reason, cause, justice, law". Ninjō can be translated as "humanity or philanthropy" [15: 150].

There is an opinion that "...nothing of the kind [giri] exists in the most important human relations of the English-speaking world: superior-subordinate, parents-children, husbandwife, brothers-sisters, friends and sometimes even enemies and business partners" [12: 256]. However, it is possible to compare this concept with the English fair play, which has been contributing to British economic prosperity for centuries. The US entrepreneurial spirit is too far from the giri principle. In addition, the English-speaking world focuses on the material component, for example, success. The Japanese culture pays more attention to personal responsibilities towards other people. Considering different social statuses, there is "the 
child's giri in relation to parents, the student's giri to the teacher, the subordinate's giri to the superior, the debtor's giri to the lender... This is typical of everyday, business and professional relationships: a person who spends leisure time with one person will not spend it with another; a buyer using the services of one merchant will not go to another" [12: 257].

Practicing moral standards is the first step to happiness in the Japanese culture. It is the principle of consent and harmony 和 $w a$, i.e. the highest goal of spiritual development. Its semantic field includes such lexemes as "peace, consent, euphony, serenity and harmony". Being an adjective, this hieroglyph takes on the meanings of "quiet, soft, meek, Japanese". It is noteworthy that the ancient name of Japan Yamato consists of two hieroglyphs: 大 (large) and 和, which allows us to interpret Yamato as "great harmony" [15].

Wa is present in all spheres of life in Japan, first of all, love for the world around and nature. Philologist I. Kurata noted, "Nature is inextricably linked with the Japanese culture and national consciousness. Snow, moon and flowers are symbols. Snow symbolizes the changing seasons and the transience of time. The moon represents space, the universe and eternity. The flower is associated with life, which is constantly changing in time and space. The Japanese believe that there is harmony and order in all manifestations of nature, even when they are aggressive towards humans" [16:31].

This ability for contemplation, connection with nature, ancestors and traditions makes the Japanese happy. In the Japanese language, happiness belongs to the ideal sphere and is perceived as something unattainable [12: 258].

\section{Conclusion}

Traditionally, the Japanese and English cultures have been regarding the concept of "happiness" in different ways. Collective and sacrificial values, reverence for ancestors and striving for harmony with others and nature typical of the Eastern world can be opposed to the spirit of enterprise, freedom and drive to personal success, common to the Western cultures.

However, the habit of mastering the Chinese borrowings was transferred to the European borrowings, which also enriched (according to some scholars, spoiled) the Japanese linguistic culture. For example, there is Hayao Miyazaki's famous cartoon Spirited Away. The animated movie takes place mainly in a traditional bathhouse for the Japanese gods and demons. Nevertheless, an elderly man Kamaji who operates the boiler room and appears as a spider wished the protagonist good luck and said, "Guddo rakku!" (barbarism from English Good luck!).

It is difficult to predict how globalization will affect various cultures in a few decades. Nowadays it is quite obvious that not only physical but also mental boundaries are opening more clearly, which leads to greater interaction of cultures.

\section{References}

1. "ももクロ、初のAKB超えタレントパワーランキング". Nihon Keizai Shimbun (in Japanese). 24 June 2013. Accessed date: July 26, 2013.

2. I. Sazo, Dotoku of Japan differs fundamentally from Western morals (Hibonsha, Tokyo, 1994)

3. Tsutomu, A. Japanese phonology: A functional approach. (2000) Accessed on: January 16, 2021. [Online]. Available:

https://books.google.ru/books/about/Japanese_phonology.html?hl=ru\&id=R-

QZAQAAIAAJ 
4. A.A. Groh, Research Methods in Indigenous Contexts (Springer, New-York, 2018)

5. E.V. Maevskii, Graficheskaya stilistika yaponskogo yazyka [The graphical stylistics of the Japanese language]. 2nd ed. (AST: Vostok-Zapad, Moscow, 2006)

6. Encyclopedia Britannica. Britannica Japan. Accessed on: December 23, 2020. [Online]. Available: https://search.rsl.ru/ru/record/01003135937

7. N. Udagawa, S. Takeda, S. Shūdan Nihongo, Manga de manabu Nihongo hyōgen to Nihon bunka: Tabeta-ke ga iku! (ALC, Tokyo, 2019)

8. L.V. Zhilina, Aspekty mentalnosti v yaponskom yazyke na primerakh etiketa $\mathrm{v}$ rechi [Mindset aspects in the Japanese language as exemplified by speaking etiquette]. Vestnik Omskogo Universiteta [Omsk University Bulletin], 4, 134-137 (2004)

9. Tsukaikata no wakaru ruigo reikai jiten (Shogakukan, Tokyo, 2003)

10. Ruigo shinjiten (Kadokawa Gakugei Shuppan, Tokyo, 2007)

11. 新明確国語辞典 Shin meikaku kokugoshiten (The New World Japanese Dictionary) (Tokyo, 1997)

12. N.N. Izotova, MGIMO University Bulletin, 3, 253-258 (2011)

13. V.G. Zinchenko, V.G. Zusman, Z.I. Kirnoze, Mezhkulturnaya kommunikatsiya. Ot sistemnogo podkhoda $\mathrm{k}$ sinergeticheskoi paradigme [Intercultural communication. From a systems approach to a synergistic paradigm] (Flinta, Nauka, Moscow, 2007)

14. Y. Mishima, Khagakure nyumon. Samuraiskaya etika v sovremennoi Yaponii [Hagakure nyūmon. The samurai ethical code in modern Japan], 266-277 (Evrazia, Saint Petersburg. 1996)

15. J. Gillepshi, Y. Sugiura, Nihon bunka o eigo de shokai suru jiten (Netsumsha, Tokyo, 1996)

16. I. Kuruta, Setsugetsuka-no kokoro (Tokyo, 1987) 